\title{
Pengaruh Etika Dan Motivasi Kerja Terhadap Produktivitas Kerja Karyawan (Studi Kasus Bank Syariah Mandiri Cabang Pembantu Pangkalan Brandan) \\ Asmawarna Sinaga ${ }^{1}$, Anjur Perkasa Alam², Yaumul Khair Afif ${ }^{3}$, Novita Mayang4, Nurfadillah ${ }^{5}$ \\ 1,2,3,4,5Sekolah Tinggi Agama Islam Jam'iyah Mahmudiyah Tanjung Pura
}

\section{Corresponding Author: Asmawarna.sinaga@yahoo.co.id}

\section{ABSTRACT}

\begin{abstract}
The Influence of Work Ethics and Motivation on Employee Work Productivity (Case Study of Bank Syariah Mandiri Sub-Branch of Pangkalan Brandan. Asmawarna Sinaga and Anjur Perkasa Alam. Purpose of this research is to know how big influence of ethics and work motivation to productivity of employees of Bank Syariah Mandiri Pangkalan Brandan. The results of ethical variables showed statistically significant results smaller than a $(0.00<0.05)$ and $t$ count $>$ table $(7,795>2.17881)$. Ttable value $=t(a / 2: n-k-1)=t(0.025: 12)$ see ttable $=2.17881$ (see ttable distribution). Then $\mathrm{HO} 1$ is rejected so it can be concluded that the variable of ethics partially significant effect on employee productivity of Bank Syariah Mandiri KCP Pangkalan Brandan. the variable of the deposit interest rate statistically shows significant results at a value smaller than $a(0.00<0.05)$ and $t$ count $>$ table $(79.538>$ 2.17881). Ttable value $=t(a / 2: n-k-1)=t(0,025: 12)$ ttable $=2,17881$ (see ttable distribution). Then HO 2 is rejected so it can be concluded that the variable of work motivation partially significant effect on work productivity of employees of Bank Syariah Mandiri KCP Pangkalan Brandan. Based on the regression equation above, work motivation $(X 2)=+0.702$ means that if every increase of 1 working motivation constant (X2) will cause the increase of work productivity of Bank Syariah Mandiri employees KCP Pangkalan Brandan (Y) by 0,702\%. Based on table 4.10 above, the inflation variable has a significance value of 0.00 is smaller than 0.05 . Then $\mathrm{HO}$ accepted so it can be concluded that the variable of work motivation have an effect on signifikan to work productivity of employees of Bank Syariah Mandiri KCP Pangkalan Brandan
\end{abstract}

Keywords Ethics, Work Motivation, Employee Productivity.

\section{PENDAHULUAN}

Perkembangan zaman terus melangkah maju dan banyak menyumbangkan perubahan-perubahan, membangun tatanan dan peradaban baru, seperti ideologiideologi kemanusiaan, life style, dan sebagainya. Perilaku budaya dan sosial manusia telah banyak mengabaikan moralitas, nilai persahabatan yang manusiawi, bahkan lebih condong pada materi, kekuasaan, kehormatan, kesenangan duniawi, dan lebih mementingkan dunianya sendiri (Alfan dan Kamaludin, 2010). Hal ini terjadi karena orientasi kehidupan manusia saat ini hanya ingin menguasai, meskipun pada hakikatnya manusia saat ini hanya dikuasai oleh emosi dan nafsunya.

Demikian pula yang terjadi pada umat islam saat ini, masih dikuasai oleh emosi dan nafsunya. Berdasarkan konteks sejarah, umat islam pernah mengalami masa kejayaan tahun 610-1250 M dan juga masa kemunduran. Faktor yang menyebabkan kemunduran umat islam salah satunya adalah adanya pengekangan berfikir, serta 
masalah pendidikan dan pengajaran yang merupakan tujuan diutusnya para Nabi. Rasulullah SAW , Bersabda "sesungguhnya aku diutus untuk menyempurnakan akhlak".

Oleh sebab itu, etika menjadi bagian paling penting dalam islam. Salah satu tokoh etika dalam islam adalah Ibnu Miskawaih. Demi memperoleh kebahagiaan dunia dan akhirat agama islam mengajarkan agar umatnya melakukan kerja keras baik dalam bentuk ibadah maupun amal sholeh. Ibadah adalah perintah yang harus dilakukan oleh umat islam yang berkaitan langsung dengan Allah SWT dan telah ditentukan secara terperinci tentang tatacara pelaksanaannya. Sedangkan amal sholeh adalah perbuatan baik yang dilakukan oleh umat islam, dimana perbuatan tersebut berdampak positif bagi dirinya sendiri, bagi masyarakat, bagi bangsa dan negara, serta bagi umat islam itu sendiri (Suseno, 1997).

Karena dengan semakin banyak perusahaan asing yang berekspansi kepada persaingan bisnis di Indonesia, maka diperlukan berbagai promosi dari dalam perusahaan untuk dapat bersaing secara wajar dan sehat dalam rangka mencapai tujuan masing-masing perusahaan. Keberhasilan promosi merupakan harapan utama bagi bank untuk meningkatkan minat nasabah. Produk - produk suatu bank memerlukan suatu promosi yang baik kepada nasabah, upaya untuk meningkatkan minat nasabah.

Dewasa ini industri perbankan merupakan salah satu mitra usaha yang dapat dipercaya dalam membantu kelancaran suatu usaha, dengan berbagai fasilitas pembiayaan dari bank yang tersedia. Bank adalah salah satu lembaga keuangan yang bergerak di bidang pelayanan jasa, harus dapat memberikan pelayanan yang terbaik (service excellent) untuk dapat memenangkan persaingan yang semakin hari semakin kopetitif. Untuk menghadapi persaingan antara lembaga perbankan yang semakin ketat, sekarang ini telah dikembangkan dalam berbagai konsep pelayanan nasabah dengan tujuan untuk mempertahankan nasabah dan menjangkau nasabah-nasabah potensial.

Untuk menjawab tantangan di atas bank syariah berlomba-lomba meningkatkan pelayanan dengan sangat menonjol dengan mengoptimalkan kemampuan komparatifnya serta menyiapkan diri untuk meningkatkan kemampuan bersaing melalui perbaikan kepada nasabahnya.

Sementara tuntutan dari nasabah semakin kritis. Nasabah menginginkan adanya pelayanan yang cepat, baik dan ramah tamah. Sikap ramah tamah itu seharusnya dimiliki oleh seorang teller. Teller adalah orang yang selalu berhubungan dengan nasabah. Teller yang menjadi tolak ukur nasabah untuk loyal terhadap sebuah bank.

Allah berfirman dalam surah Al-Luqman ayat 6

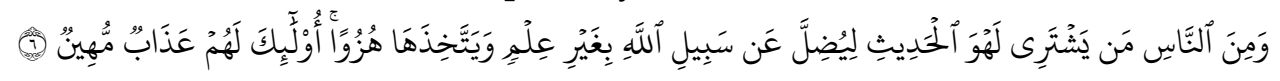

Artinya : "Dan di antara manusia (ada) orang yang mempergunakan perkataan yang tidak berguna untuk menyesatkan (manusia) dari jalan Allah tanpa pengetahuan dan menjadikan jalan Allah itu olok-olokan. mereka itu akan memperoleh azab yang menghinakan".(QS.Luqman:6) 
Didirikannya Bank Syariah dilatar belakangi oleh keinginan umat islam untuk menghindari riba dalam kegiatan muamalahnya : memperoleh kesejahteraaan lahir batin melalui kegiatan muamalah yang sesuai dengan perintah agamanya. Adapun Bank Syariah merupakan lembaga keuangan yang berfungsi sebagai perantara bagi pihak yang berkelebihan dana dengan pihak yang kekurangan dana untuk kegiatan usaha dan kegiatan lainnya sesuai dengan hukum Islam (Ali, 2008). Bank Syariah juga biasa disebut Islamic Banking atau Interest fee Banking, yaitu suatu sistem perbankan dalam pelaksanaann operasionalnya tidak menggunakan sistem bunga (riba), spekulasi (masisir),dan ketidak pastian atau ketidak jelasan (gharar). Allah SWT berfirman dalam surah Al-Baqarah : 278, yaitu :

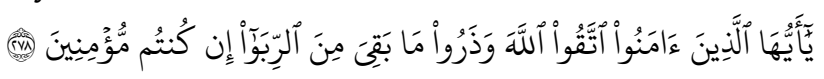

Artinya : "Hai orang-orang yang beriman, bertakwalah kepada Allah dan tinggalkan sisa riba (yang belum dipungut) jika kamu orang-orang yang beriman.

Ayat di atas menjelaskan tentang riba, namun persoalan riba tersebut bukan termasuk dalam akad perbankan. Sebagai mana firman Allah SWT dalam surah AlMaidah : 1, yaitu :

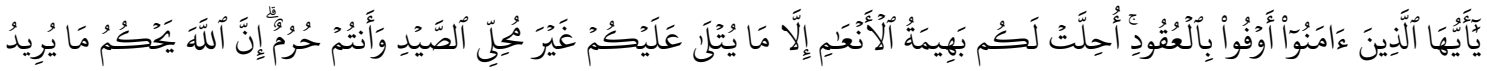

Artinya: "Hai orang-orang yang beriman, penuhilah aqad-aqad itu. dihalalkan bagimu binatang ternak, kecuali yang akan dibacakan kepadamu. (yang demikian itu) dengan tidak menghalalkan berburu ketika kamu sedang mengerjakan haji. Sesungguhnya Allah menetapkan hukum-hukum menurut yang dikehendaki-Nya".

Penjelasan ayat di atas adalah Aqad (perjanjian) mencakup: janji prasetia hamba kepada Allah dan perjanjian yang dibuat oleh manusia dalam pergaulan sesamanya.

$$
\text { عن أبي هرير قال إن الله يقول أ ذا ثا لث الثريكينما لميخن أ حد هما صا حبه }
$$

Artinya : "Dari Abu Hurairah, Rasulullah Saw bersabda, 'sesungguhnya Allah Azza wa jalla berfirman, "aku pihak ketiga dari dua orang yang berserikat selama salah satunya tidak menghianati lainnya". ( HR Abu Dawud no.2936, dalam kitab al-Buyu, dan Hakim)

Bekerja adalah salah satu bentuk ibadah yang dilakukan di dunia. Bekerja dengan etika kerja yang benar sesuai ajaran islam merupakan syarat mutlak untuk mencapai kebahagiaan dunia dan akhirat. Sebab, dengan menggunakan etika yang baik dapat meningkatkan semangat kerja yang berpengaruh dalam meningkatkan produktivitas kerja. Hal ini dkarenakan nilai etika, moral, atau akhlak adalah nilai-nilai yang mendorong manusia menjadi pribadi yang utuh seperti kejujuran, kebenaran, keadilan, kemerdekaan, kebahagiaan, dan cinta kasih. Setiap orang boleh mempunyai seperangkat pengetahuan, tetapi pengetahuan yang mengarahkan dan mengendalikan perilaku orang islam hanya ada dua yaitu Al-Qur'an dan Hadist sebagai sumber segala nilai dan pedoman dalam setiap sendi kehidupan, termasuk dalam bisnis (Hasan, 2009).

Dari penjelasan diatas dapat ditarik kesimpulan bahwa sesungguhnya penghayatan agama yang diwujudkan dalam bentuk iman yang sempurna, 
mempunyai hubungan timbal balik dengan etika atau akhlak seseorang. Seseorang yang memiliki iman yang sempurna, dipastikan memiliki etika kerja yang baik pula. Karena etika kerja islami tidak mengajarkan untuk mendurhakai Allah dalam bekerja. Yaitu dengan meningkatkan kejujuran, keadilan, dan semangat dalam bekerja sehingga target dapat tercapai dengan meningkatnya produktivitas tanpa adanya tindakan yang menyimpang seperti korupsi.

Etika berasal dari bahasa latin yaitu 'etos' yang berarti kebiasaan. Sedangkan bahasa Arabnya 'akhlak' yang berarti budi pekerti. Keduanya dapat diartikan sebagai suatu kebiasaan atau adat istiadat yang menunjuk kepada perilaku manusia itu sendiri, tindakan atau sikap yang dianggap benar atau baik. Etika kerja islami menekankan pekerjaan kreatif sebagai sumber kebahagiaan dan prestasi. Kerja keras dianggap sebagai kebajikan dan orang yang bekerja keras lebih besar kemungkinan hidupnya akan lebih maju, sebaliknya tidak bekerja keras dianggap menyebabkan kegagalan. Nilai etika kerja islami dihasilkan dari keinginan diri sendiri, tanpa adanya paksaan dari pihak manapun.

Permasalahan lain yang terdapat dalam meningkatkan produktivitas kerja adalah motivasi kerja. Target suatu perusahaan akan dapat tercapai apabila kinerja dari karyawan yang ada didalamnya memiliki motivasi kerja yang tinggi. Di dalam AlQur'an terdapat ayat yang menyuruh dan memotivasi bekerja. Dengan bkerja dan berpenghasilan manusia dapat memenuhi kebutuhannya. Dalam surat Al-Jum'ah ayat 10 Allah telah menegaskan :

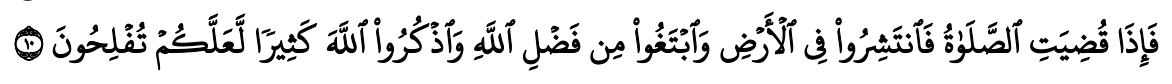

Artinya : Apabila telah ditunaikan shalat, maka bertebaranlah kamu dimuka bumi, dan carilah karunia Allah dan ingatlah Allah banyak-banyak supaya kamu beruntung".

Persaingan yang ketat atau tuntutan nasabah terhadap pelayanan bank yang lebih sempurna merupakan faktor pendorong adanya inovasi dan adanya perubahan bisnis perbankan. Nasabah telah mengakui dan menyadari apa yang sesungguhnya di inginkan nasabah dan memilih apa yang terbaik. Dipihak lain nasabah juga tidak menginginkan prosedur yang panjang dan rumit untuk setiap transaksi perbankan. Kenyamanan dan kemudahan menjadi tujuan perusahaan perbankan.

Untuk menjawab tantangan diatas bank syariah berlomba-lomba meningkatkan pelayanan dengan menonjolkan dan mengoptimalkan keunggulan komparatifnya serta menyiapkan diri untuk meningkatkan kemampuan bersaing melalui perbaikan pelayanan terhadap nasabahnya. Masing-masing bank berusaha menampilkan dirinya sebaik mungkin agar dapat menarik minat nasabah untuk menabung.

Kualitas pelayanan merupakan jaminan terbaik dari kesetiaan pelanggan. Kualitas pelayanan yang lebih tinggi akan menghasilkan kepuasan nasabah yang tinggi pula. Oleh karena itu program penyempurnaan kualitas pada umumnya akan meningkatkan profitabilitas nasabahnya.

Pada umumnya, kunci untuk memenangkan persaingan adalah memberikan kepuasan kepada konsumennya., sehingga terciptanya sebuah keputusan pada konsumen untuk menggunakan jasa. Pada tahap inilah bank harus menyenangkan hati 
konsumen agar konsumen tertarik pada setiap produk-produk yang ditawarkan, salah satu strateginya adalah dengan meningkatkan kualitas pelayanan. Di harapkan dengan kualitas pelayanan yang baik, maka kepuasan konsumen akan tercapai sehingga dengan adanya kepuasan, keputusan akan tercipta.

Selain dengan meningkatkan kualitas pelayanan, ternyata komunikasi juga sangat penting, karena tanpa adanya komunikasi yang baik, maka kualitas pelayanan tidak akan terlaksana dengan baik. Salah satunya dengan menggunakan komunikasi interpersonal. Komunikasi interpersonal adalah proses penyampaian, penerimaan pesan antara pengirim pesan dengan penerima pesan baik secara langsung maupun tidak langsung (Suranto, 2011). Setelah terjadinya pertukaran informasi antara penerima pesan dan pengirim pesan diharapkan terjadi sebuah perubahan perilaku. Dengan layanan komunikasi yang baik akan berpengaruh positif terhadap keputusan menjadi nasabah. Dalam persaingan yang semakin meningkatnya bank harus aktif didalam meningkatkan usahanya baik untuk mendapatkan nasabah baru yang potensial maupun untuk mempertahankan nasabah lama (Sukandarunnidi, 2004).

Sedangkan motivasi kerja dalam Islam itu adalah untuk mencari nafkah yang merupakan bagian dari ibadah. Motivasi kerja dalam Islam bukanlah untuk mengejar hidup hedonis, bukan juga untuk status, apalagi untuk mengejar kekayaan dengan segala cara, tapi juga dilakukan untuk beribadah. Ketika motivasi dihubungkan dengan niat dan niat dihubungkan dengan keikhlasan maka hal ini sangat sulit diukur. Kata niat jika disejajarkan lebih tinggi dari kata motivasi. Dari pemaparan diatas dapat di simpulkan bahwa motivasi adalah pengaruh yang didapatkan dari dalam dan luar diri kita sendiri.

Berdasarkan latar belakang masalah di atas,maka rumusan masalah yang akan dibahas dalam penelitian ini adalah Bagaimanakah pengaruh antara etika kerja terhadap peningkatan produktivitas kerja karyawan Bank Syariah Mandiri Cabang Pembantu Pangkalan Brandan? dan Bagaimanakah pengaruh motivasi kerja terhadap peningkatan produktivitas kerja karyawan Bank Syariah Mandiri Cabang Pembantu Pangkalan Brandan?

Adapun tujuan penelitian ini adalah untuk mengetahui bagaimana pengaruh antara etika kerja terhadap peningkatan produktivitas kerja karyawan Bank Syariah Mandiri Cabang Pembantu Pangkalan Brandan dan untuk mengetahui bagaimana pengaruh motivasi kerja terhadap peningkatan produktivitas kerja karyawan Bank Syariah Mandiri Cabang Pembantu Pangkalan Brandan.

Adapun penelitian sebelumnya yang terkait dengan pengaruh etika kerja dan motivasi kerja islam terhadap produktivitas kerja karyawan (studi kasus Bank Syariah Mandiri Cabang Pembantu Pangkalan Brandan) adalah penelitian oleh Agus Lukman Fitriyan tahun 2011 yang berjudul pengaruh etika kerja dan motivasi kerja islam terhadap produktivitas kerja karyawan (studi kasus pada karyawan Bank BNI Syariah Cabang Medan) yang menyimpulkan bahwa etika dan motivasi sangat mempengaruhi produktivitas kerja karyawan Bank BNI Syariah. 
Ho 1: tidak terdapat pengaruh yang signifikan secara parsial antara etika terhadap produktivitas kerja karyawan Bank Syariah Mandiri KCP Pangkalan Brandan.

$\mathrm{H}_{1} 1$ : tidak terdapat pengaruh yang signifikan secara parsial antara etika terhadap produktivitas kerja karyawan Bank Syariah Mandiri KCP Pangkalan Brandan.

Ho 2 : terdapat pengaruh yang signifikan secara parsial antara motivasi kerja terhadap produktivitas kerja karyawan Bank Syariah Mandiri KCP Pangkalan Brandan.

$\mathrm{H}_{1} 2$ : tidak terdapat pengaruh yang signifikan secara parsial antara motivasi kerja terhadap produktivitas kerja karyawan Bank Syariah Mandiri KCP Pangkalan Brandan.

Ho 3 : terdapat pengaruh yang signifikan secara simultan antara etika dan motivasi kerja terhadap produktivitas kerja karyawan Bank Syariah Mandiri KCP Pangkalan Brandan.

$\mathrm{H}_{1} 3$ : terdapat pengaruh yang signifikan secara simultan antara etika dan motivasi kerja terhadap produktivitas kerja karyawan Bank Syariah Mandiri KCP Pangkalan Brandan.

\section{METODOLOGI PENELITIAN}

Penelitian bersifat kuantitatif dengan memaparkan data secara deskriptif sehingga memberikan pemahaman dan kejelasan dari penelitian. Variabel yang ada dalam penelitian ini adalah pengaruh etika dan motivasi kerja terhadap produktivitas karyawan (studi kasus Bank Syariah Mandiri Cabang Pembantu Pangkalan Brandan).

Lokasi penelitian dilakukan di Bank Syariah Mandiri Cabang Pembantu Pangkalan Brandan. Bank ini merupakan salah satu Bank Syariah yang terdapat di Pangkalan Brandan. Bank Syariah Mandiri ini sangat dekat dengan kota sehingga mudah dijangkau oleh nasabah dengan berbagai alat transportasi. Adapun waktu penelitian dilaksanakan pada bulan Januari sampai dengan bulan Maret 2017.

Populasi adalah "Jumlah keseluruhan dari unit analisa yang ciri-cirinya akan diteliti, ....dalam setiap penelitian populasi yang dipilih erat hubungannya dengan masalah yang ingin dipelajari" (Efendi dan Singarimbun, 1990). Dengan kata lain, populasi adalah keseluruhan objek yang akan diteliti. Adapun populasi dalam penelitian ini meliputi seluruh nasabah Bank Sumut Syariah Cabang pembantu Binjai.

Sampel adalah "Cara pengumpulan data dengan jalan mencatat dan meneliti sebahagian kecil dari seluruh elemen yang menjadi objek penelitian" (Sudijono, 2008). Dengan demikian, sampel adalah wakil dari kelompok populasinya.

Cara pengambilan sampel menurut pendapat Suharsimi Arikunto yang menyatakan bahwa: "hasil penelitian sampel berlaku bagi populasi, maka sampel yang diambil harus refresentatif, yaitu mewakili populasi dalam arti semua ciri-ciri atau karakteristik yang ada dalam populasi tercermin pada sampel" (Arikunto, 1998). Maka sampel dalam penelitian ini adalah 40 orang nasabah. Dengan kata lain penulis mempergunakan sampel random yaitu sebahagian nasabah Bank Sumut Syariah Cabang pembantu Binjai. Hal ini disebabkan jumlah populasi yang cukup banyak sehingga sulit penulis dalam hal pengumpulan data. 
Untuk keperluan pengujian hipotesis penelitian ini, maka dalam hal ini perlu dilakukan teknik pengumpulan data, yaitu menggunakan non tes. Teknis non tes yang digunakan dalam penelitian ini menggunakan angket untuk mengumpulkan data tentang pengaruh etika dan motivasi kerja terhadap produktivitas kerja karyawan. Bentuk angket yang digunakan adalah angket tertutup, yaitu dengan menyediakan pilihan jawaban untuk setiap pertanyaan.

Setelah penulis menerima kembali angket yang diberikan kepada responden, maka angket telah dapat diolah datanya. Pengolahan data hasil angket adalah dengan cara tabulasi yaitu dalam bentuk tabel. Pertama kali penulis mencari frekuensi responden yang memilih satu alternatif jawaban yang telah disediakan pada setiap pertanyaan yang diajukan. Selanjutnya dari jumlah frekuensi yang didapat dicari presentasenya. Jadi dengan cara tabulasi akan diketahui frekuensi dan persentase dari alternatif pilihan jawaban dari setiap pertanyaan yang ada dalam angket. Hasil tabulasi tersebut akan dianalisis. Penganalisisan data hasil tabulasi ini adalah dengan memberikan ungkapan atau pernyataan kuantitatif terhadap jumlah persentase yang diperoleh dalam tabulasi. Sedangkan pengolahan data dari hasil wawancara kepada kepala cabang Bank Sumut Syariah Cabang Pembantu Binjai dilakukan dengan cara memberikan kesimpulan terhadap wawancara tersebut. Dengan kesimpulan itu, peneliti dapat memahami bagaimana hubungan setiap variable yang ada.

Variabel penelitian adalah segala sesuatu yang berbentuk apa saja yang ditetapkan oleh peneliti untuk dipelajari sehingga diperoleh informasi tentang hal tersebut, kemudian ditarik kesimpulannya. Variabel penelitian ini terdiri dari dua kelompok utama yaitu variabel dependen dan variabel independen. Berikut ini adalah pengukuran masing- masing variabel yang diajukan dalam penelitian ini terdiri dari: Variabel dependen yaitu variabel yang dipengaruhi oleh variabel lain. Variabel ini dinyatakan dalam tanda Y. Variabel dependen dalam penelitian ini adalah produktivitas kerja karyawan Bank Syariah Mandiri KCP Pangkalan Brandan. Yang dimaksud produktivitas adalah kemampuan karyawan dalam berproduksi dibandingkan dengan input yang digunakan, seorang karyawan dapat dikatakan produktif apabila mampu menghasilkan barang atau jasa sesuai dengan diharapkan dalam waktu yang singkat atau tepat selain itu.

Variabel independen yaitu variabel yang mempengaruhi variabel lain, variabel ini dinyatakan dalam tanda $X$. Variabel independen dalam penelitian ini yaitu: $X_{1}$ Etika dan X2 Motivasi Kerja.

Metode pengumpulan data yang digunakan dalam penelitian ini adalah menggunakan kuesioner secara personal. Teknik ini memberikan tanggung jawab kepada responden untuk membaca dan menjawab pertanyaan dan peneliti dapat memberikan penjelasan mengenai tujuan survei dan pertanyaan yang kurang dipahami oleh responden serta tanggapan atas kuesioner dapat langsung dikumpulkan oleh peneliti setelah diisi oleh responden. Kuesioner secara personal digunakan untuk mendapatkan data tentang dimensi-dimensi dari kontruk-kontruk yang sedang dikembangkan dalam penelitian ini. 
Pertanyaan-pertanyaan dalam kuesioner dibuat dengan menggunakan skala 1-5 untuk mendapatkan data yang bersifat interval dan diberi skor atau nilai. Skala Likert menurut adalah skala yang digunakan untuk mengukur sikap, pendapat, dan persepsi seseorang atau sekelompok orang tentang fenomena sosial. Dalam skala Likert variabel yang diukur dijabarkan menjadi indikator variabel. Kemudian indikator tersebut dijadikan sebagai titik tolak untuk menyusun item-item instrumen yang dapat berupa pernyataan atau pertanyaan.

Bobot Nilai Instrumen

\begin{tabular}{|c|l|c|}
\hline SS & Sangat Setuju & 5 \\
\hline S & Setuju & 4 \\
\hline KS & Kurang Setuju & 3 \\
\hline TS & Tidak Setuju & 2 \\
\hline STS & Sangat Tidak Setuju & 1 \\
\hline
\end{tabular}

Teknik analisa dalam penelitan ini menggunakan teknik analisis diskriptif kuantitatif. Analisis deskriptif kuantitatif yaitu suatu metode penelitian yang bersifat menggambarkan kenyataan atau fakta sesuai dengan data yang diperoleh dengan tujuan untuk mengetahui kualitas layanan dan minat nasabah untuk menggunakan jasa.

Berikut adalah metode yang digunakan dalam menganalisis data pada penelitian ini: Penggunaan statistik deskriptif variabel penelitian dimaksudkan untuk memberikan penjelasan yang memudahkan peneliti dalam menginterpretasikan hasil analisis data dan pembahasannya. Statistik deskriptif berhubungan dengan pengumpulan dan peringkasan data serta penyajiannya yang biasanya disajikan dalam bentuk tabulasi baik secara grafik dan atau numeric. Pengujian asumsi klasik adalah untuk memberikan kepastian bahwa persamaan regresi yang didapatkan memiliki ketepatan dalam estimasi, tidak biasa dan konsisten. Perlu diketahui, terdapat kemungkinan data aktual tidak memenuhi semua asumsi klasik ini. Beberapa perbaikan, baik pengecekan kembali data outlier maupun recollecterror data dapat dilakukan. Uji asumsi klasik yang dilakukan pada penelitian ini antara lain: pengujian normalitas, pengujian multikolinieritas, pengujian heteroskedastisitas dan pengujian otokorelasi. Uji normalitas dilakukan untuk melihat apakah variabel bebas dan variabel terikat mempunyai distribusi normal. Maksud data distribusi normal adalah data akan mengikuti arah garis diagonal dan menyebar disekitar garis diagonal. Uji normalitas dimaksudkan untuk menguji apakah nilai residual yang telah distandarisasi pada model regresi berditribusi normal atau tidak. Nilai residual dikatakan berdistribusi normal jika nilai residual terstandarisasi tersebut sebagian besar mendekati nilai rata-ratanya.

Nilai residual terstandarisasi yang berdistribusi normal jika digambarkan dalam bentuk kurva akan membentuk gambar lonceng (bell-shaped curve) yang kedua sisinya melebar hingga sampai tidak terhingga. Dalam penelitian ini, peneliti menggunakan uji normalitas dengan analisis grafik. Adapun dasar pengambilan keputusan dalam uji 
ini adalah sebagai berikut : Histogram, Normal Probability Plot (Normal P-P Plot dan Uji Kolmogorov-Smirnov.

Peneliti menggunakan uji normalitas dengan Kolmogorov-Smirnov. Nilai residual terstandarisasi berdistribusi normal jika nilai Signifikansi (Sig) > alpha (a) atau K hitung < K table. Multikolinearitas adalah hubungan linier antar variabel independen di dalam regresi berganda. Model regresi yang baik seharusnya tidak terjadi korelasi diantara variabel independen. Yaitu munculnya peluang diantara beberapa variabel bebas untuk saling berkorelasi, pada praktiknya multikolinieritas tidak dapat dihindari. Mengukur multikolinieritas dapat dilihat dari nilai Tolerance dan Variance Inflation Factor (VIF). Tolerance mengukur variabilitas variabel independen lainnya. Jadi nilai tolerance yang rendah sama dengan nilai VIF tinggi karena VIF = $1 /$ tolerance. Nilai cut off yang umum dipakai untuk menunjukkan adanya multikolinieritas adalah nilai tolerance $<0.10$ atau sama dengan VIF $>10$. Hipotesis yang digunakan dalam pengujian multikolinieritas adalah :

1) $\mathrm{H}_{0}:$ VIF $>10$, terdapat multikolinieritas

2) $\mathrm{H}_{1}: \mathrm{VIF}<10$, tidak terdapat multikolinieritas.

Heteroskedastisitas yaitu kondisi dimana semua residual atau error mempunyai varian yang tidak konstan atau berubah-ubah. Untuk mengetahui apakah suatu data bersifat heteroskedastisitas atau tidak, maka perlu pengujian. Pengujian heteroskedastisitas pada penelitian ini menggunakan metode Analisis Grafik dan metode Rank Spearman. Metode analisis grafik dilakukan dengan mengamati scatterplot di mana sumbu horizontal menggambarkan Predicted Standardized sedangkan sumbu vertikal menggambarkan nilai Residual Studentized. Jika scatterplot membentuk pola tertentu, hal itu menunjukkan adanya masalah heteroskedastisitas pada model regresi yang dibentuk.

Uji Otokorelasi bertujuan menguji apakah dalam model regresi linear ada korelasi antara kesalahan pengganggu pada periode $t$ dengan kesalahan pengganggu pada periode $\mathrm{t}-1$. Uji otokorelasi bertujuan untuk mengetahui apakah ada korelasi antara anggota serangkaian data observasi yang diuraikan menurut waktu (time-series) atau ruang (cross section). Salah satu penyebab munculnya masalah otokorelasi adalah adanya kelembaman (inertia) artinya kemungkinan besar akan mengandung saling ketergantungan (interdependence) pada data observasi periode sebelumnya dan periode sekarang.

Salah satu ukuran dalam menentukan ada tidaknya masalah otokorelasi adalah dengan uji Durbin-Watson (DW) dengan ketentuan sebagai berikut :

1) Terjadi otokorelasi positif, jika nilai DW dibawah -2 (DW <-2)

2) Tidak terjadi otokorelasi, jika nilai DW berada diantara -2 dan +2 atau $-2 \leq$ $\mathrm{DW} \leq+2$

3) Terjadi otokorelasi negatif jika nilai DW diatas +2 atau DW $>+2$

Menentukan ada tidaknya masalah otokorelasi adalah dengan uji DurbinWatson (DW) dengan ketentuan sebagai berikut (Santoso, 2012) :

1) Angka D-W dibawah -2, berarti ada autokorelasi positif 
2) Angka D-W diantara -2 sampai +2 , berarti tidak ada autokorelasi

3) Angka D-W diatas +2 , berarti ada autokorelasi negative

Dalam melakukan pengujian hipotesis, penulis memakai $\alpha=5 \%(0,05)$ atau tingkat kepercayaan 95\%. Metode pengujian hipotesis dalam penelitian ini adalah sebagai berikut : Uji t digunakan untuk mengetahui ada tidaknya pengaruh masingmasing variabel independen secara individual (parsial) terhadap variable dependen yang diuji pada tingkat signifikasi 0.05 maka variabel independen berpengaruh terhadap variabel dependen. Nilai thitung digunakan untuk menguji pengaruh secara parsial (per variabel) terhadap terikatnya. Apakah variabel tersebut memiliki pengaruh yang berarti terhadap variabel terikatnya atau tidak.

Adapun dasar pengambilan keputusan pada Uji $t$ adalah sebagai berikut :

1. Jika nilai sig $<0,05$, atau $t_{\text {hitung }}>t_{\text {tabel }}$ maka terdapat pengaruh variabel $X$ terhadap Y.

2. Jika nilai sig $>0,05$, atau $t_{\text {hitung }}<t_{\text {tabel }}$ maka tidak terdapat pengaruh variabel $X$ terhadap $\mathrm{Y}$.

Uji-F digunakan untuk menguji koefisien bersama-sama, sehingga nilai dari koefisien regresi tersebut dapat diketahui secara bersama (Usman dan Nachrowi, 2006). Menurut pendapat lain Uji F hitung digunakan untuk menguji pengaruh secara simultan variabel bebas terhadap variabel terikatnya atau untuk menguji ketepatan model (goodness of fit). Jika variabel bebas memiliki pengaruh secara simultan terhadap variabel terikat maka model persamaan regresi masuk dalam kriteria cocok atau fit. Sebaliknya, jika tidak terdapat pengaruh secara simultan maka masuk dalam kategori tidak cocok atau not fit.

Adapun cara pengujian dalam uji $\mathrm{F}$ ini, yaitu dengan menggunakan suatu tabel yang disebut dengan Tabel ANOVA (Analysis of Variance) dengan melihat nilai signifikasi ( $\operatorname{Sig}<0,05$ atau $5 \%$ ). Jika nilai signifikasi $>0.05$ maka $\mathrm{H}_{1} 3$ ditolak,

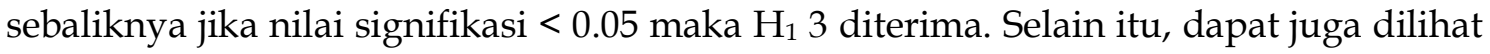
dari nilai $\mathrm{F}$ hitung dan $\mathrm{F}$ tabel. Jika $\mathrm{F}_{\text {hitung }}>\mathrm{F}_{\text {tabel }}$ maka variabel bebas secara simultan berpengaruh terhadap variabel terikatnya di mana $F_{\text {tabel }}=\mathrm{F}(\mathrm{k}: \mathrm{n}-\mathrm{k})$. Dimana $\mathrm{n}=$ jumlah pengamatan, $\mathrm{k}=$ jumlah variabel.

Adapun dasar pengambilan keputusan pada Uji $\mathrm{F}$ adalah sebagai berikut :

1. Jika nilai sig $<0,05$, atau $F_{\text {hitung }}>F_{\text {tabel }}$ maka terdapat pengaruh variabel $X$ terhadap Y.

2. Jika nilai sig $>0,05$, atau $\mathrm{F}_{\text {hitung }}<\mathrm{F}_{\text {tabel }}$ maka tidak terdapat pengaruh variabel $\mathrm{X}$ terhadap $\mathrm{Y}$.

a. $\quad$ Uji Koefisien Determinasi $\left(\mathrm{R}^{2}\right)$

Koefesiensi determinasi $\left(\mathrm{R}^{2}\right)$ digunakan untuk mengukur seberapa baik garis regresi sesuai dengan data aktualnya (goodness of fit). Koefisiensi determinasi ini mengukur prosentase total varian variabel dependen $\mathrm{Y}$ yang dijelaskan oleh variabel independen di dalam garis regresi. Nilai $R^{2}$ mempunyai interval antara 0 sampai $1(0<$ $\mathrm{R}^{2}<1$ ). Semakin besar $\mathrm{R}^{2}$ (mendekati 1 ), semakin baik hasil untuk model regresi 
tersebut dan semakin mendekati 0 , maka variabel independen secara keseluruhan tidak dapat menjelaskan variabel dependen.

Koefisien Determinasi $\left(\mathrm{R}^{2}\right)$ bertujuan untuk mengetahui seberapa besar kemampuan variabel independen menjelaskan variabel dependen. Nilai $R$ square berada diantara 0 - 1, semakin dekat nilai $R$ square dengan 1 maka garis regresi yang digambarkan menjelaskan 100\% variasi dalam Y. Sebaliknya, jika nilai R square sama dengan 0 atau mendekatinya maka garis regresi tidak menjelaskan variasi dalam $\mathrm{Y}$ (Sulaiman, 2004).

Koefisien determinasi merupakan besarnya kontribusi variabel bebas terhadap variabel terikatnya. Semakin tinggi koefisien determinasi, semakin tinggi kemampuan variabel bebas dalam menjelaskan variasi perubahan pada variabel terikatnya. Dengan menggunakan koefisien determinasi yang disesuaikan maka nilai koefisien determinasi yang disesuaikan itu dapat naik atau turun oleh adanya penambahan variabel baru dalam model.

Pada analisis regresi berganda bahwa regresi berganda variabel tergantung (terikat) dipengaruhi oleh dua atau lebih variabel bebas sehingga hubungan fungsional antara variabel terikat $(Y)$ dengan variabel bebas $\left(X_{1}, X_{2}, X_{n}\right)$. Kemudian dapat ditulis sebagai berikut (Suliyanto, 2011) :

$$
\mathrm{Y}=\mathrm{f}\left(\mathrm{X}_{1}, \mathrm{X}_{2}, \ldots . ., \mathrm{Xn}\right)
$$

Keterangan :

$\mathrm{Y}=$ Variabel tergantung atau terikat (dependent)

$\mathrm{X} 1, \mathrm{X} 2, \ldots, \mathrm{Xn}=$ Variabel bebas (independent)

Secara piktografik model fungsional di atas dapat digambarkan sebagai berikut :

\section{Gambar 3.1}

Model Piktografis Regresi berganda

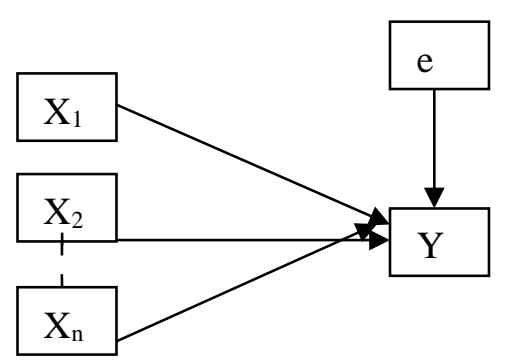

Dalam gambar 3.1 diatas terlihat bahwa variabel tergantung (terikat) dipengaruhi dua atau lebih variabel bebas, disamping itu juga terdapat pengaruh regresi linier berganda dapat dituliskan sebagai berikut :

$$
Y=a+b_{1} X_{1}+b_{2} X_{2}+\ldots \ldots+b n X n+e
$$


Journal Economy And Currency Study (JECS)

Volume 2, Issue 2 July 2020

Page 44-53

Keterangan :

$\mathrm{Y}=$ Variabel tergantung atau terikat (nilai yang diproyeksikan)

$\mathrm{a}=$ Intercept (konstanta)

$b_{1}=$ Koefisien regresi untuk $X_{1}$

$X_{1}=$ Variabel bebas pertama

$b_{2}=$ Koefisien regresi untuk $X_{2}$

$\mathrm{X}_{2}=$ Variabel bebas kedua

$\mathrm{Bn}=$ Koefisien regresi untuk $\mathrm{Xn}$

$\mathrm{X} n=$ Variabel bebas ke $\mathrm{n}$

$\mathrm{e}=$ Nilai residu

Berdasarkan pemaparan di atas maka model persamaan analisis regresi linier berganda pada penelitian ini adalah sebagai berikut:

$$
\mathrm{PK}=\mathrm{a}+\mathrm{b}_{1} \mathrm{ET}+\mathrm{b}_{2} \mathrm{MK}+\mathrm{e}
$$

Keterangan:

PK = Produktivitas Kerja, Variabel terikat $(\mathrm{Y})$

$\mathrm{a}=$ Intercept (konstanta)

$\mathrm{b}_{1} \quad=\quad$ Koefisien regresi untuk $\mathrm{X}_{1}$

$\mathrm{b}_{2} \quad=\quad$ Koefisien regresi untuk $\mathrm{X}_{2}$

ET $=$ Etika, variabel bebas pertama $\left(X_{1}\right)$

$\mathrm{MK}=$ Motivasi Kerja, variabel bebas kedua $\left(\mathrm{X}_{2}\right)$

e $\quad=\quad$ Nilai residu

\section{HASIL DAN PEMBAHASAN}

Berdasarkan hasil analisis dan pembahasan yang telah dipaparkan pada bab sebelumnya, maka dapat diambil kesimpulan sebagai berikut:

Hasil Uji t menunjukkan bahwa variabel bebas etika dan motivasi kerja secara parsial atau individu memiliki pengaruh signifikan terhadap produktivitas kerja karyawan Bank Syariah Mandiri KCP Pangkalan Brandan. Variabel etika secara statistik menunjukkan hasil yang signifikan pada nilai lebih kecil dari a $(0,00<$ $0,05)$ dan $t_{\text {hitung }}>$ tabel $(7,795>2,17881)$, maka $\mathrm{H}_{0} 1$ ditolak sehingga dapat disimpulkan bahwa variabel etika berpengaruh signifikan terhadap produktivitas kerja karyawan Bank Syariah Mandiri KCP Pangkalan Brandan. Variabel motivasi kerja secara statistik menunjukkan hasil yang signifikan pada nilai lebih besar dari a $(0,00<0,05) t_{\text {hitung }}>$ tabel $(79,538>2,17881)$, maka $\mathrm{H}_{0} 2$ ditolak sehingga dapat disimpulkan bahwa variabel motivasi kerja berpengaruh terhadap produktivitas kerja karyawan Bank Syariah Mandiri KCP Pangkalan Brandan.

Hasil Uji F menunjukkan bahwa variabel bebas yang diteliti yaitu etika dan motivasi kerja secara simultan berpengaruh signifikan terhadap terhadap produktivitas kerja karyawan Bank Syariah Mandiri KCP Pangkalan Brandan. Variabel etika dan motivasi kerja secara statistik menunjukkan hasil yang signifikan lebih kecil dari a $(0,00<0,05)$ dan nilai $F_{\text {hitung }}>F_{\text {tabel }}(49,126>4,10)$, maka $\mathrm{H}_{0} 3$ ditolak. Dapat disimpulkan bahwa etika dan motivasi kerja secara simultan berpengaruh siginifikan 
Journal Economy And Currency Study (JECS)

Volume 2, Issue 2 July 2020

Page 44-53

terhadap produktivitas kerja karyawan Bank Syariah Mandiri KCP Pangkalan Brandan.

\section{KESIMPULAN}

Berdasarkan hasil analisis dan pembahasan yang telah dipaparkan pada bab sebelumnya, maka dapat diambil kesimpulan sebagai berikut:

Hasil Uji t menunjukkan bahwa variabel bebas etika dan motivasi kerja secara parsial atau individu memiliki pengaruh signifikan terhadap produktivitas kerja karyawan Bank Syariah Mandiri KCP Pangkalan Brandan. Variabel etika secara statistik menunjukkan hasil yang signifikan pada nilai lebih kecil dari a $(0,00<$ $0,05)$ dan $t_{\text {hitung }}>$ tabel $(7,795>2,17881)$, maka $\mathrm{H}_{0} 1$ ditolak sehingga dapat disimpulkan bahwa variabel etika berpengaruh signifikan terhadap produktivitas kerja karyawan Bank Syariah Mandiri KCP Pangkalan Brandan. Variabel motivasi kerja secara statistik menunjukkan hasil yang signifikan pada nilai lebih besar dari a $(0,00<0,05) t_{\text {hitung }}>$ tabel $(79,538>2,17881)$, maka $\mathrm{H}_{0} 2$ ditolak sehingga dapat disimpulkan bahwa variabel motivasi kerja berpengaruh terhadap produktivitas kerja karyawan Bank Syariah Mandiri KCP Pangkalan Brandan.

Hasil Uji F menunjukkan bahwa variabel bebas yang diteliti yaitu etika dan motivasi kerja secara simultan berpengaruh signifikan terhadap terhadap produktivitas kerja karyawan Bank Syariah Mandiri KCP Pangkalan Brandan. Variabel etika dan motivasi kerja secara statistik menunjukkan hasil yang signifikan lebih kecil dari a $(0,00<0,05)$ dan nilai $F_{\text {hitung }}>F_{\text {tabel }}(49,126>4,10)$, maka $\mathrm{H}_{0} 3$ ditolak. Dapat disimpulkan bahwa etika dan motivasi kerja secara simultan berpengaruh siginifikan terhadap produktivitas kerja karyawan Bank Syariah Mandiri KCP Pangkalan Brandan.

Adapun saran dari penelitian ini adalah menyarankan kepada Bank Syariah Mandiri KCP Pangkalan Brandan agar membuat mood kerja karyawan dan terus melakukan pencerahan kepada para karyawannya karena dari hasil penelitian menunjukkan bahwa etika dan motivasi kerja karyawan berpengaruh positif terhadap produktivitas kerja, jika produktivitas kerja naik maka yang diuntungkan adalah Bank itu sendiri dan penelitian ini juga diharapkan dapat menjadi salah satu tambahan referensi mengenai perbankan syariah bagi peneliti maupun bagi peneliti selanjutnya yang tertarik untuk meneliti tentang topik sejenis yaitu produktivitas kerja pada perbankan syariah khususnya di Bank Syariah Mandiri KCP Pangkalan Brandan. Selain itu juga dapat dijadikan bahan referensi tambahan bagi kepustakaan pihak kampus. Untuk peneliti selanjutnya sebaiknya memperbanyak jumlah variabel seperti : gaji, insentif, bonus, kenaikan jabatan dan lainnya. Periode penelitian dapat diperbaharui atau lebih lama agar hasil yang didapat lebih dapat menjelaskan berbagai fenomena yang terjadi berkaitan dengan penelitian ini. 
Journal Economy And Currency Study (JECS)

Volume 2, Issue 2 July 2020

Page 44-53

\section{DAFTAR PUSTAKA}

Al-Qur'an dan Terjemahannya

Anwar Mangkunegara, Manajemen Sumber Daya manusia perusahaan, Bandung:PT. Rosda Karya, 2004.

Arifin, Johan, Fiqih Perlinsungan Konsumen, Semarang:Rasail, 2007.

Departemen Agama RI, Al-Qur'an dan Terjemah, Jakarta:Pusaka Assalam, 2010.

Djamarah, Saiful Bahri, Psikologi Belajar, Jakarta:PT Rieneka Cipta,2011.

Hasan, Ali, Manajemen Bisnis Syari'ah, Yogyakarta : Pustaka Belajar,2009.

K. Bertens, Etika, Jakarta: Gramedia Pustaka Utama, 2011.

Suseno, Frans Margin, 13 Tokoh Etika, Yogyakarta:Kanisius, 1997.

Sutrisno, Eddy, Kamus Populer Bahasa Indonesia, Jakarta: Sinergi Pustaka Indonesia, 2010.

Undang Ahmd Kamaludin dan Muhammad Alfan, Etika Manajemen Islam, Bandung: CV. Pustaka Setia, 2010. 